hydrochloric acid no odour could be detected when the digests were prepared under reflux.

The odoriferous compound was thus fairly volatile, and it could be extracted into ether from the digests. Evaporation gave a pale brown syrup in which no nitrogen could be detected, and which gave a spectrum in water with a single strong peak at $2300 \mathrm{~A}$.

Paper chromatograms of threonine digested at $110^{\circ}$ or $120^{\circ} \mathrm{C}$. showed much unchanged threonine and the presence of traces of glycine and $\alpha$-amino-nbutyric acid (as already shown by Heyns and Walter ${ }^{1}$ ). Digestion at $140^{\circ} \mathrm{C}$. resulted in much greater destruction, and some alanine appeared. Some trouble was experienced in identifying $\alpha$-amino- $n$-butyric acid on chromatograms, since with an isatin spray, specific for proline ${ }^{2}$, this compound gave a dull blue colour. This was found to be due to the presence of excess hydrochloric acid, since authentic $\alpha$-amino$n$-butyric acid, when applied to the paper in $6 \mathrm{~N}$ hydrochloric acid, also gave a blue colour. The odoriferous compound was found to run at $R_{F} \sim 0.90$ in phenol saturated with water and in butanol-acetic acid-water (5:1:4 by vol.).

In the amino-acid analysis of hydrochloric acid hydrolysates of proteins, a correction of 5-10 per cent is generally added to the values for serine and threonines. Measurements made here on threonine digests showed $a_{0}$ loss of 7-9 per cent of $\alpha$-amino- $\alpha$ carboxylic acid (van Slyke-ninhydrin-carbon dioxide method) in $15 \mathrm{hr}$. digestion at $110^{\circ} \mathrm{C}$. in $6 \mathrm{~N}$ hydrochloric acid, whereas ammonia determinations showed that 3 per cent of the total nitrogen appeared as ammonia in this time. When $11 \mathrm{~N}$ hydrochloric acid was used, 10 per cent of the total nitrogen appeared as ammonia, and at $140^{\circ} \mathrm{C}$. the corresponding ammonia values in 6 and $11 N$ hydrochloric acid were 64 and 73 per cent. Gas, which was identified as carbon dioxide, was produced during the digestions, especially at $140^{\circ} \mathrm{C}$.

It is readily possible, therefore, to detect threonine in protein and peptide hydrolysates by a characteristic odour, and while the destruction of the threonine produces small amounts of glycine $\theta^{1}$ and $\alpha$-amino- $n$ butyric acid ${ }^{1}$, ammonia, and at higher temperatures alanine and carbon dioxide, the nature of the odoriferous substance is unknown.

I wish to thank Mr. D. A. Maguire for technical assistance.

\section{M. P. PhILlips}

Department of Biochemistry,

Australian National University, Canberra, A.C.T.

Feb. 26.

1 Heyns, K., and Walter, W., Naturwiss., 22, 507 (1952).

Acher, R., Fromageot, C., and Jutisz, M., Biochim. et Biophys. Acta. 5, 81 (1950).

'Rees, M. W., Biochem. J., 40, 632 (1946).

\section{Volatile Acids of Ox Perinephric Fat}

INVESTIGATIONS on the fatty-acid composition of ox fat have revealed the presence of a consecutive series of volatile fatty acids from $\mathrm{C}_{2}$ to $\mathrm{C}_{10}$. Prior to this communication, there appears to be no record of fatty acids with molecular weight lower than that of $\mathrm{C}_{10}{ }^{1}$ occurring in animal depot fats, with the exception of isovaleric acid in porpoises and dolphins ${ }^{2}$. The presence in milk fats of $\mathrm{C}_{4}-\mathrm{C}_{10}$ volatile fatty acids with an even number of carbon atoms has long been known and this knowledge has been supplemented by the identification in 1951 of acetic acid in goat milk fat. In recent times, however, volatile fatty acids have also been reported as occurring in the perienteric fluid of Ascaris lumbricoides from the pig, in rumen contents of sheep, in grass-water slurries, in the fatty substances present in human hair, in the skin secretions (hair grease) of a number of animals, and in the liver lipids of rabbits and rats.

A sample of beef suet $(J / 21)$ from the fat surrounding the kidneys was steam-rendered, and the glycerides after neutralization were hydrogenated using a nickel catalyst. The hydrogenated glycerides were saponified with potassium hydroxide, the soaps converted to fatty acids with 40 per cent sulphuric acid, and the fatty acids steam-distilled. The steam distillate was neutralized with potassium hydroxide, taken to dryness on the water-bath, and the soaps obtained were dissolved in water and made up to a $2 \mathrm{~N}$ solution.

Using the gas-liquid partition chromatogram of James and Martin ${ }^{3}$, and the procedure suggested by them for the determination of fatty acids isolated as their potassium soaps, a complete analysis of the volatile fatty acids from $\mathrm{C}_{2}$ to $\mathrm{C}_{10}$ was carried out. The fatty acids were separated by passage through a column of 'Celite $545^{\prime}$ ' and 'D.C. 550 '/ stearic acid at $137^{\circ} \mathrm{C}$. The results are shown in the table.

\begin{tabular}{|c|c|c|c|}
\hline \multirow{2}{*}{ Acids found } & \multicolumn{3}{|c|}{$\begin{array}{l}\text { Retention volumes of fatty acids relative } \\
\text { to that of } n \text {-butyric acid }\end{array}$} \\
\hline & $x$ & $\underset{Y}{\substack{Y \\
Y}}$ & $Z$ \\
\hline $\begin{array}{l}\text { Acetic } \\
\text { Propionic } \\
\text { n-Butyric } \\
n-\text { Valeric } \\
n \text {-Caproic } \\
n \text {-Heptylic } \\
n \text {-Octanoic } \\
n \text {-Nonanoic } \\
n \text {-Decanoic }\end{array}$ & $\begin{array}{c}0 \cdot 26 \\
0 \cdot 54 \\
1 \cdot 00 \\
1 \cdot 89 \\
3 \cdot 58 \\
6 \cdot 59 \\
12 \cdot 2 \\
21 \cdot 6 \\
39 \cdot 0\end{array}$ & $\begin{array}{r}0 \cdot 26 \\
0.54 \\
1 \cdot 00 \\
1 \cdot 87 \\
3 \cdot 43 \\
6 \cdot 59 \\
12 \cdot 2 \\
21 \cdot 6 \\
39 \cdot 0\end{array}$ & $\begin{array}{c}0.26 \\
0.54 \\
1.00 \\
1.91 \\
3.58 \\
6.55 \\
12 \cdot 0 \\
22 \cdot 0 \\
40.5\end{array}$ \\
\hline
\end{tabular}

$X$, Values for a synthetic mixture of $\mathrm{C}_{2}$ to $\mathrm{C}_{10}$ acids ; $Y$, values for acids isolated from beef suet; $Z$, values for a synthetic mixture of $C_{2}$ to $\mathrm{C}_{10}$ acids as reported by James and Martin (ref. 3 ).

Apart from the nine acids reported above, an unidentified acid was found with a retention volume relative to that of $n$-butyric acid of $27 \cdot 6$, and this value suggests that it may be an isomer of decanoic acid.

It is of interest to note that odd-numbered fatty acids are among those identified in the present investigation. As both odd- and even-numbered fatty acids from $\mathrm{C}_{2}$ to $\mathrm{C}_{10}$ have been found, it seems possible that, in addition to the higher even-numbered fatty acids known to occur in beef tallow ${ }^{3}$, there may elso be present higher fatty acids of the odd-numbered series".

A detailed account of this work will be published elsewhere.

\section{R. P. HANSEN}

A. G. McInnes

Fats Research Laboratory

(Department of Scientific and Industrial Research), Sydney Street West,

Wellington, C.1, New Zealand. Feb. 18.

1 Hansen, R. P., and Cooke, N. J., Biochem. J., 54, 14 (1953),

2 Lovern, J. A., Biochem. J., 28, 394 (1934).

' Lovern, J. A., Biochem. J., T., and Martin, A. J. P., Biochem. J., 50, 679 (1952).

- Hansen, R. P., Shorland, F. B., and Cooke, N. J., Nature (in the press). 